\title{
Corporate Governance Disclosure and Security's Market Risk in The United Arab Emirates
}

\author{
Md Hamid Uddin ${ }^{1} \&$ Mostafa Kamal Hassan ${ }^{2}$ \\ ${ }^{1}$ Department of Finance and Economics, University of Sharjah, United Arab Emirates \\ ${ }^{2}$ Department of Accounting, University of Sharjah, United Arab Emirates \\ Correspondence: Md Hamid Uddin, Department of Economics and Finance, College of Business Administration, \\ University of Sharjah, PO Box 27272, Sharjah, United Arab Emirates. Tel: 971-6-5055-0517. E-mail: \\ mduddin@sharjah.ac.ae oriba_hu@yahoo.com
}

Received: April 12, 2013

Accepted: July 25, 2013

Online Published: December 23, 2013

doi:10.5539/ijef.v6n1p39

URL: http://dx.doi.org/10.5539/ijef.v6n1p39

\begin{abstract}
The paper examines the relationship between the corporate governance and security's market risk for a sample of 95 companies listed in the two stock markets of the United Arab Emirates (UAE). The empirical test uses the security's 'beta coefficient' as dependent variable and weighted and un-weighted corporate governance indices as explanatory variables while controlling for the effects of factors such as such as firms size, financial leverage, operating leverage, industry type. The results show that weighted corporate governance disclosure index has significant negative effect on the security's market risk in the UAE capital markets, yet the effect of un-weighted index is not significant. However, the effect is not uniform across the sample companies, particularly the disclosure of corporate governance information do not affect the market risk of the low operating leverage firms as well as that of the finance firms. The study sheds new light on the underlying factors that structure the relationship between the governance and market valuation of corporate firms.
\end{abstract}

Keywords: corporate governance, market risk, firm valuation, corporate governance index

\section{Introduction}

There has been growing interest in improving governance standards in corporate firms across the world. Scholars who advocate for better governance believe that good corporate governance increases a firm's market valuation. Newell and Wilson's (2002) study provides evidence that institutional and private investors are willing to pay a premium to well-governed firms. Likewise, other researchers found that firms' value and performance increase with the level of governance (Black, 2001; Gompers et al., 2003; Joh, 2003; Black et al., 2006). Love (2011) suggests a positive association between corporate governance and various measures of performance, including the security value. He adds that corporate governance is likely to develop endogenously based on the firm's specific characteristics and surrounding environment.

In this paper, we examine the underlying cause of relationship between the level of corporate governance and security valuation following asset pricing theory, which suggests that the market value of risky securities is lower than that of the low-risk securities. This is because investors require additional return to compensate for additional risk, and, without expectation of higher return, they will not invest in risky securities. Therefore, the required rate of return is negatively related to security valuation in the financial market. Given the above knowledge, the Capital Asset Pricing Model (CAPM) suggests that investors' required return is determined by the level of a security's market risk, although arbitrage pricing theory (APT) argues that the required return may also depend on different macro-economic factors. However, the mainstream literature on security valuation that developed on the basis of CAPM framework suggests that a security's market risk measured by 'beta coefficient' is the sole factor that determines the required rate of return.

Although beta coefficient is considered the primary determining factor of required return, Fama and French (1993) and Acharya and Perderson (2005) identified that other factors such as firm size, book-to-market ratio, and liquidity also affect the required return. Given the effect of other factors, the role of beta coefficient in determining the investor's required return is still well accepted in the literature. In this regard, we know from asset pricing theory that investors' required rate of return is to be related to market valuation of securities. Hence, 
any change in the security's market risk factor (beta coefficient) may affect the investors' required return and the valuation of corporate firms may thereby also be affected. Given the earlier evidence of positive relationship between the firm value and corporate governance, we may conjecture that improvement in the governance standards can reduce the uncertainty of investment in the equities of well-governed corporate firms. Thereby, market valuation of corporate firms increases due to reduced market risk. The studies mentioned above have generally reported a positive association between the valuation of corporate firms and their governance quality and standards, but none examined a possible underlying reason that could be related to asset pricing theory. Therefore, we have tried to fill the gap by making efforts to understand why the market valuation of well-governed firms should be higher than that of the other firms from the perspective of asset pricing theory.

We examined the above research issue in the context of emerging markets, using data from two capital markets of the United Arab Emirates (UAE). It is noted that in 2012 the UAE, with US\$360 billion of Gross Domestic Product (GDP) and ranking in the second position within the Middle East and North African (MENA) region after Saudi Arabia, has emerged as a major financial and economic hub due to its openness to international business, trade, and investment. A news article (Note 1) reports that more than 3000 foreign companies are operating in the UAE, accounting for about $16 \%$ of total investment inflows to all Arab economics. Although the UAE economy has achieved rapid growth over the last several decades, the corporate sector began to flourish from 2000 when the Abu Dhabi Exchange (ADX) and Dubai Financial Market (DFM) were established. As of 2010, a total of 130 firms are listed on ADX and DFM with combined market capital of 93.77 billion dollars. With the progress of the corporate sector and financial market development in the UAE, the governance of corporate firms becomes an important issue for the investors and corporations. Therefore, following the OECD principles, the UAE Securities and Commodity Authority (SCA) framed its own corporate governance code in 2007 for the firms incorporated within the country, or any firm listed on a securities market licensed by the SCA (e.g., ADX and DFM).

Therefore, an examination of the effect of corporate governance on the security's market risk will help us to understand the effectiveness of the UAE governance codes framed for the ADX and DFM listed companies. Recently, Aljiifri and Moustafa (2007; 2012), Hassan (2012), and Al-Tamimi (2012) have investigated different aspects of corporate governance practices in the UAE corporate firms, but none focuses on the current research issue, whether improvement in the governance level can reduce the level of security market risk of the listed firms. Hence this paper enhances the current knowledge on corporate governance practices in the UAE, while enriching the literature by making efforts to understand whether better corporate governance results in lower security market risk for the listed firms. The research issue has policy implications about the corporate governance practices and investment risks. If more corporate governance disclosure lowers the risk of investment, regulators may incorporate relevant guidelines to ensure more transparency in corporate disclosures, which is particularly important for emerging economies such as the UAE.

In investigating the subject, we use two different corporate governance disclosure indices (un-weighted and weighted) following the OECD principles of corporate governance (2004), UAE corporate governance code of 2007, and prior international studies that are intended to reflect the level of governance standard in corporate firms. The weighted index gives more importance to the international corporate governance standards, while the un-weighted index gives equal importance to local and international standards. The regression results based on 95 sample firms listed on the Dubai and Abu Dhabi stock markets reveal that the weighted corporate governance disclosure index has a significant negative effect on the level of security's beta coefficient - suggesting that improvements in the governance standards leads to reduction in the market risk of corporate firms. However, the insignificant effect of un-weighted index indicates that investors tend to rely more on the international corporate governance standards than on local standards. It is also found that the effect of corporate governance disclosure on the market risk is not uniform across the samples; specifically, the disclosure of corporate governance information does not affect the market risk of the low operating leverage firms or finance firms.

The rest of this paper is organized as follows: in the next section, the relevant literature is reviewed and a hypothesis is framed. In the subsequent sections, we describe respectively the research methodology, sample and data characteristics and empirical findings. Finally, the conclusion is given in the last section.

\section{Literature Review and Hypothesis}

The relationship between the corporate governance and firm valuation is well documented in the literature. In addition to the evidence provided earlier, Ammann et al. (2011) provide more comprehensive evidence on the corporate governance and firm valuation based on 6663 firm-year observations from 22 developed countries over the period 2004 to 2007. Using a set of corporate governance indices based on 64 individual governance 
attributes, they found a strong and positive relation between firm-level corporate governance and firm valuation. Similar evidence is also found in emerging countries such as Venezuela (Garay \& Gonzalez, 2008), India (Balasubramanian et al., 2010), China (Hu et al., 2010), and Bangladesh (Farooque et al., 2007). The review of extant literature on the relationship between the corporate governance and firm valuation shows that various factors relating to corporate ownership structure and internal governance mechanism, management and board structure, corporate leadership structure (CEO duality), and agency problem between different stakeholders could affect the valuation of corporate firms.

Among the major studies on ownership structure and internal governance mechanism, Stulz (1988) and Slovin and Sushka (1993) found that shareholders' wealth increases with decreases in ownership concentration in developed markets. However, evidence from emerging markets showed that non-managerial block holdings are positively related to firm value in 18 emerging markets (Lins, 2003). Regarding the board structure and firm valuation, most studies found a negative relationship between the board size and firm value (e.g., Andres et al., 2005; Mak \& Kusnadi, 2005). It is also found that board independence, audit committee, and independent directors in the board generally improve the market valuation of corporate firms (Black \& Kim, 2012; Cotter \& Silvester, 2003; Lei \& Song, 2012). With respect to corporate leadership structure, neither theoretical nor empirical studies provide consensus as to whether firms with split titles (CEO and Board Chairman being two different persons) outperform firms with combined titles (CEO and Board Chairman being the same person). For example, Fama and Jensen (1983) and Jensen (1993) suggest that CEO duality reduces firm monitoring and thereby increases agency cost, while Stoeberl and Sherony (1985) and Anderson and Anthony (1986) argue that CEO duality provides clear-cut leadership in strategy formulation and implementation and will therefore lead to better firm performance that may result in higher market valuation of securities. In a nutshell, the primary focus of these studies is to understand why and how the different corporate governance mechanisms can affect the firm performance and its market valuation.

The review of other relevant literature shows that different corporate governance mechanisms, as mentioned in the above literature, affect agency problems in the corporate firms in different manners, and thereby the valuation of these firms could be affected. Gorton and Khal (2008) argued that agency problems in corporate firms are prevalent because the ownership structure is usually developed in such a way that the wealthy investors with corporate governance ability do not maintain block holding of issued shares unless such block holding increases the value of firm. Florackis and Ozkan (2009) using the UK data found that there is a strong negative relationship between managerial entrenchment and agency costs. McKnight and Weir (2009) found that increase of board ownership helps to reduce agency costs, while formation of nomination committee increases the agency cost. Fernandes (2008) found that firms with no nonexecutive board members actually have fewer agency problems and achieve a better alignment of shareholders' and managers' interest. Schmid and Zimmermann (2008) found that firm value rises with increases in CEO equity holdings up to a certain point (around 40-50\%) and then declines with further increases above the point. They suggest that the potential for agency costs associated with combining the leadership functions (CEO and Chairman) may be controlled by providing reasonable equity incentives for the CEO-cum-Chairman. Based on above review of literature we conclude that different corporate governance mechanisms primarily aim at reducing the agency problems in corporate firms that helps increase in firm value.

It is important to understand why the reduced agency problems due to different corporate governance mechanisms should increase the value of firm. Shleifer and Vishny (1997) mentioned that corporate governance mechanisms consists of rules, structures and procedures by which investors can assure themselves of obtaining a fair return on their investments and ensure that managers will not misuse their funds. Hart (1995) and Porta et al. (2000) argued that investors' interests are protected and agency problems are reduced with proper implementation of code of corporate governance. Therefore, we conjecture that the risk of investment can be reduced through lower agency problems if the firms are governed on the basis of the defined corporate governance rules and standards. We should note here that agency problems may usually be less if the governance codes are legally enforced, instead of leaving them for voluntary practice. This conjecture is consistent with the findings of Chong and Silanes (2007) that investors' legal protection due to the mandatory governance codes has a positive correlation with the valuation of firms. However, Klapper and Love (2004) and Love (2011) found in contrast that effective governance at micro organizational level is possible if corporate firms voluntarily adopt various good governance practices to protect their investors' interest. This is particularly important in countries where the legal environment is weak.

In either of the means (enforcement or voluntary), if the corporate firms follow the governance codes with due diligence, the investors benefit as the risk of investment is reduced due to the reduced agency problems. This 
analysis is consistent with the evidence provided by Skaife et al. (2004) that effective corporate governance practice reduces agency risks at the firm level. Now, based on the asset pricing theory, we argue that investors should demand less required return if their risk is reduced due to fewer agency problems in the well-governed firms. Given this argument, since it is known that the investors' required return from a security depends on the level of its market risk factor (beta coefficient), we can assert that the corporate governance practices will affect the security market risk of a firm. Hence, the following hypothesis has been constructed for empirical test.

HA: The better the level of governance in the UAE corporate firms the lower will be the level of security's market risk factor.

This hypothesis implies a negative relationship between the level of corporate governance practices and the security market risk of the corporate firms listed on the ADX and DFM.

\section{Methodology}

This paper aims to examine the effect of corporate governance practices on the level of the market risk of UAE firms listed on the Dubai and Abu Dhabi stock markets. Therefore, we first define the variables as follows:

\subsection{Market Risk Factor}

The market risk factor for each sample company is measured by estimating the beta coefficient $(\beta)$ as follows. In estimating the beta coefficient, we use 52 weekly returns (Note2) over a one-year period following publication of the annual report (Note 3) for 2008.

$$
R_{t}=\alpha+\beta R_{m}+e_{t}
$$

Where $R_{t}$ is the return of sample firm for the week $t$, and $R_{m}$ is the corresponding market return for the same week and calculated based on DFM all share price index for Dubai companies and ADX all share index for Abu Dhabi companies. The beta estimate $(\beta)$ is adjusted for thin-trading effect by using Dimson (1979) method with three lag and lead returns.

\subsection{Corporate Governance Disclosure Index}

The levels of corporate governance practices in the UAE corporate firms are measured following Hassan's (2012) approach (see Appendix 1). A Corporate Governance Disclosure Index (CGDI) for each of the sample firms is constructed based on the OECD principles of corporate governance (2004), UAE corporate governance code of 2007, and the earlier studies (Note 4) on crafting governance index. The potential disclosure items and their classifications are identified after reviewing the OECD principles and prior studies, and adjusted according to UAE code of corporate governance. The CGDI includes a total of 42 items spanned over the four categories: ownership structure and investors' rights (11 items); board and management structure and processes (10 items); external auditing and audit service (4 items) and transparency and disclosure (17 items). The details on CGDI items are provided in Appendix 1. The individual company's disclosures across the above items are identified by reviewing the annual reports of 2008 and other relevant documents. A score table is prepared with a value of 0 or 1,1 if an item is disclosed and 0 otherwise. An un-weighted CGDI (CGDI_U) is computed by the adding the scores across the 42 items. A weighted CGDI (CGDI_W) is also computed by assigning weights to disclosed items. If disclosed item complies with the OECD and literature then 3 points are given, if disclosed item is beyond the OECD, literature, and UAE corporate governance code but considered it as useful, then 2 points are given. If the disclosed item only complies with UAE code then 1 point is given (for details see Hassan, 2012).

Hassan's (2012) weighted index and un-weighted index are useful for several reasons. First, both indices blend the UAE regulatory requirements with worldwide governance practices. Second, the weighted index adds a quantitative dimension to explore whether the UAE corporations advocate the voluntary publication of corporate governance information. Third, the weighted index also considers the socio-political context in the UAE. Hassan's (2012) indices, therefore, can assist the UAE regulators, institutional investors, and international investment community to understand the status of the corporate governance in the UAE and the underlying level of transparency in the disclosure of governance practices.

Having estimated the above variables the effect of corporate governance on the level of security's market risk is tested by estimating a number of multivariate regression models with the stock's beta coefficient (BETA) as dependant variable and the corporate governance indices (CGDI_U and CGDI_W) as explanatory variables along with the following control variables.

\subsection{Control Variables}

Among the prior studies, Hamada (1972), Thompson II (1976), and Mandelker, Rhee (1984) and Ho et al. (2004) 
documented that a corporation's operating leverage, financial leverage, dividends and earning instability play major role in determining the security's market risk. In addition, literature suggests that degree of security's risk can be affected by firm size and book-to-market ratio. Therefore, the following variables are considered as control variables.

DFL: degree of financial leverage of sample firms is measured as total debt divided by total shareholders' equity.

DOL: degree of operating leverage of sample firms is measured as $\log (\mathrm{EBIT}) / \log ($ Sales $)$.

DIV: dividend payout ratio is measured as dividend per share (DPS) divided by earning per share (EPS): DPS/EPS.

EPS: earning per share is measured as net income divided by number of shares outstanding.

SIZE: average market size of a sample firm is calculated as (TMV_B + TMV_E)/2; where, TMV_B is the total market of value of the firm at beginning of financial year and TMV_E is the total market value at the end of financial year.

MVBV: market-to-book value ratio is calculated as average market value per share divided by book value per share. The average market value is calculated as $\left(\mathrm{P}_{\mathrm{B}}+\mathrm{P}_{\mathrm{E}}\right) / 2$, where $\mathrm{P}_{\mathrm{B}}$ denotes the market price at the beginning of financial year and $\mathrm{P}_{\mathrm{E}}$ is the market price at end of financial year.

INDFIN: this is a dichotomous variable, INDFIN $=1$ if the sample firm belongs to Bank and Financial Service sector, otherwise INDFIN $=0$. This variable is needed because the degrees of financial leverage for bank financial companies are usually higher than the other firms.

\section{Samples and Data Description}

The sample includes a total of 95 companies listed on the Dubai Financial Market (DFM) and Abu Dhabi Exchange (ADX), who published their annual reports for 2008 . The sample size covers about $73 \%$ of the whole UAE capital market. The distribution of samples, presented in Table 1 below, shows that a total of 26 companies (27\%) are from the Insurance sector, followed by 18 companies (19\%) from the Bank sector and 14 companies (15\%) from the Industrial sector. In addition, nine companies $(9.5 \%)$ are from the Financial Services sector and eight companies $(8.42 \%)$ are from the Real Estate and Consumer Staple sectors respectively. The remaining 12 companies (12.63\%) are from the Energy, Services, Telecom and Transportation sectors. Overall, this shows that samples are drawn from all sectors, although the majority of samples are from the Bank, Financial Services and Insurance sectors. However, this resembles the market structure since the majority of companies are listed in these three sectors.

Table 1. Industry distribution of sample firms

\begin{tabular}{lcccc}
\hline Industrial Sector & DFM Listed Firms & ADX Listed Firms & Total Listed Firms & Samples \\
\hline Bank & 12 & 14 & 26 & 18 \\
Financial Services & 11 & 3 & 14 & 9 \\
Insurance & 13 & 17 & 30 & 26 \\
Industrial & 5 & 12 & 17 & 14 \\
Real Estate & 9 & 3 & 12 & 8 \\
Consumer Staple & 5 & 5 & 10 & 2 \\
Energy & 0 & 2 & 10 & 5 \\
Services & 3 & 7 & 5 & 2 \\
Telecom & 2 & 3 & 4 & 3 \\
Transportation & 4 & 0 & 130 & 95 \\
Total & 64 & 66 & 2010. & 5 \\
\hline
\end{tabular}

DFM is Dubai Financial Market and ADX is Abu Dhabi Exchange. Listed firms data as of the year 2010. 
Table 2. Descriptive statistics of sample firms

\begin{tabular}{lcccccccccc}
\hline \multicolumn{10}{c}{ Panel A: Full Sample Descriptive Statistics } \\
\hline Statistics & BETA & $C G I \_U$ & $C G I_{-} W$ & $D F L$ & $D O L$ & $E P S$ & DIV & SIZE & MVBV & FIN \\
\hline Mean & 0.64 & 22.84 & 50.79 & 2.34 & 16.02 & 5.18 & 4.95 & 6.04 & 1.18 & 0.28 \\
Median & 0.46 & 23.00 & 51.00 & 1.09 & 16.08 & 0.28 & 2.40 & 6.06 & 0.85 & 0.00 \\
Mode & 0.00 & 25.00 & 48.00 & $\# \mathrm{~N} / \mathrm{A}$ & $\# \mathrm{~N} / \mathrm{A}$ & 0.08 & 0.00 & 5.27 & 0.00 & 0.00 \\
Standard Deviation & 0.62 & 4.65 & 10.59 & 2.95 & 1.91 & 19.16 & 8.44 & 0.91 & 0.95 & 0.45 \\
Kurtosis & -1.06 & 0.15 & 0.12 & 3.37 & 0.15 & 26.52 & 21.47 & 19.93 & 1.84 & -1.08 \\
Skewness & 0.52 & 0.12 & 0.12 & 1.85 & -0.46 & 4.89 & 4.14 & -3.04 & 1.42 & 0.97 \\
Minimum & -0.11 & 11.00 & 25.00 & 0.00 & 10.41 & -1.87 & 0.00 & 0.00 & 0.00 & 0.00 \\
Maximum & 2.10 & 36.00 & 81.00 & 14.77 & 19.63 & 135.31 & 54.59 & 7.90 & 4.54 & 1.00 \\
Count & 95.00 & 95.00 & 95.00 & 95.00 & 95.00 & 95.00 & 95.00 & 95.00 & 95.00 & 95.00 \\
\hline
\end{tabular}

Panel B: Sub-Sample Descriptive Statistics: Firms Listed in Dubai Financial Market (DFM)

\begin{tabular}{lcccccccccc}
\hline \multicolumn{1}{c}{ Statistics } & BETA & CGI_U & CGI_W & DFL & DOL & EPS & DIV & SIZE & MVBV & FIN \\
\hline Mean & 0.69 & 22.59 & 49.89 & 2.47 & 15.72 & 8.20 & 5.72 & 5.99 & 1.09 & 0.32 \\
Median & 0.43 & 23.00 & 50.50 & 1.13 & 15.84 & 0.22 & 1.32 & 6.01 & 0.78 & 0.00 \\
Mode & 0.00 & 22.00 & 48.00 & \#N/A & \#N/A & 0.08 & 0.00 & \#N/A & 0.73 & 0.00 \\
Standard Deviation & 0.69 & 4.68 & 10.59 & 3.23 & 2.15 & 26.32 & 11.37 & 0.70 & 0.93 & 0.47 \\
Kurtosis & -1.51 & 0.08 & 0.11 & 4.18 & -0.87 & 14.10 & 13.14 & -0.61 & 4.82 & -1.41 \\
Skewness & 0.34 & -0.27 & -0.21 & 2.01 & -0.29 & 3.69 & 3.52 & -0.03 & 2.05 & 0.81 \\
Minimum & -0.01 & 11.00 & 25.00 & 0.01 & 11.30 & -1.87 & 0.00 & 4.35 & 0.00 & 0.00 \\
Maximum & 2.07 & 32.00 & 73.00 & 14.77 & 19.13 & 135.31 & 54.59 & 7.29 & 4.54 & 1.00 \\
Count & 44.00 & 44.00 & 44.00 & 44.00 & 44.00 & 44.00 & 44.00 & 44.00 & 44.00 & 44.00 \\
\hline
\end{tabular}

\begin{tabular}{lcccccccccc}
\hline \multicolumn{10}{c}{ Panel C: Sub-Sample Descriptive Statistics: Firms Listed in Abu Dhabi Exchange (ADX) } \\
\hline \multicolumn{1}{c}{ Statistics } & BETA & CGI_U & CGI_W & DFL & DOL & EPS & DIV & SIZE & MVBV & FIN \\
\hline Mean & 0.59 & 23.06 & 51.57 & 2.23 & 16.28 & 2.58 & 4.28 & 6.07 & 1.25 & 0.25 \\
Median & 0.46 & 23.00 & 51.00 & 1.03 & 16.19 & 0.30 & 2.60 & 6.09 & 0.91 & 0.00 \\
Mode & 0.42 & 23.00 & 57.00 & $\# \mathrm{~N} / \mathrm{A}$ & \#N/A & 0.31 & 0.00 & 5.89 & 0.00 & 0.00 \\
Standard Deviation & 0.55 & 4.66 & 10.63 & 2.71 & 1.66 & 8.92 & 4.66 & 1.06 & 0.97 & 0.44 \\
Kurtosis & -0.46 & 0.22 & 0.08 & 1.89 & 2.03 & 24.33 & 1.16 & 21.58 & 0.27 & -0.68 \\
Skewness & 0.68 & 0.46 & 0.39 & 1.61 & -0.46 & 4.82 & 1.27 & -3.72 & 0.98 & 1.16 \\
Minimum & -0.11 & 15.00 & 32.00 & 0.00 & 10.41 & -0.26 & 0.00 & 0.00 & 0.00 & 0.00 \\
Maximum & 2.10 & 36.00 & 81.00 & 10.47 & 19.63 & 53.50 & 19.23 & 7.90 & 4.07 & 1.00 \\
Count & 51.00 & 51.00 & 51.00 & 51.00 & 51.00 & 51.00 & 51.00 & 51.00 & 51.00 & 51.00 \\
\hline
\end{tabular}

BETA is stock's market risk, CGDI_U is unweighted corporate governance disclosure index, CGDI_W is weighted corporate governance disclosure index; DFL is degree of financial leverage measured by the debt to equity ratio; DIV is the dividend payout per share, Size is the $\log$ of average market size of sample firms; MVBV is the average market-to-book ratio of the sample firms; EPS is earning per share; DOL is the degree of operating leverage measure as $\log (\mathrm{EBIT}) / \log (\mathrm{Sales})$; INDFIN is the dichotomous variable, INDFIN $=1$, if the sample firm belongs to Bank and Financial Service sector, otherwise INDFIN $=0$. It is noted that that the sub-samples statistics broadly depict similar pattern like the full sample statistics. However, due to limited space in Table 2, we have reported the descriptive statistics for the Dubai and Abu Dhabi firms only.

We also report the descriptive statistics of the test variables for the full sample and sub-samples: DFM and ADX firms. Table 2 below shows that the distributions of BETA (security's market risk), CGI_U (unweighted corporate governance index) and CGI_W (weighted corporate governance index) are insignificantly skewed 
towards the right side in both the full-sample and sub-sample data sets. The kurtosis values of these distributions are however less than 3 . Therefore, it is likely that the probability for extreme values in these data sets is less than for a normal distribution. Table 2 also shows that the distributions of control variables: DFL (degree of financial leverage), EPS (earning per share), DIV (dividends), and SIZE (firm size) are not normally distributed as the skewness and kurtosis values are beyond the normal level. In order to obtain consistent estimates from regression analyses, we have cleaned these data sets by removing the outlier values. It is noted that that the sub-samples statistics broadly depict similar pattern like the full sample statistics. However, due to limited space in Table 2, we have reported the descriptive statistics for the Dubai and Abu Dhabi firms only.

\section{Results and Discussions}

We first examine the bivariate correlations among the variables to observe any association between the different pairs of variables. The results presented in Table 3 below show that BETA has a significant relationship with five variables: CGDI_W, SIZE, MVBV, EPS and DOL. Among these, the BETA is negatively related to CGDI_W, MVBV and EPS and positively related to SIZE and DOL. The significant negative relationship between the BETA and CGDI_W indicates that the UAE corporate firms that are professionally managed and comply with the adopted codes of corporate governance tend to be the less risky firms in the market. The insignificant relationship between the BETA and CGDI_U implies that each piece of information in the index has different importance to the investors, and hence BETA instead displays relationship with the weighted corporate governance index (CGDI_W).

Table 3. Correlations results $(\mathrm{N}=95)$

\begin{tabular}{|c|c|c|c|c|c|c|c|c|c|c|}
\hline & 1 & 2 & 3 & 4 & 5 & 6 & 7 & 8 & 9 & 10 \\
\hline & BETA & CGDI_U & CGDI_W & DFL & DIV & SIZE & MVBV & EPS & DOL & INDFIN \\
\hline BETA & 1 & & & & & & & & & \\
\hline CGDI_U & -.156 & 1 & & & & & & & & \\
\hline CGDI_W & $-.238^{*}$ & $.85^{* *}$ & 1 & & & & & & & \\
\hline DFL & .042 & $.536^{* *}$ & $.497^{* *}$ & 1 & & & & & & \\
\hline DIV & -.097 & -.118 & -.107 & -.088 & 1 & & & & & \\
\hline SIZE & $.229^{*}$ & $.218^{*}$ & $.208^{*}$ & $.276^{* *}$ & -.077 & 1 & & & & \\
\hline MVBV & $-.437^{* *}$ & -.095 & -.106 & -.006 & $-.229^{*}$ & .062 & 1 & & & \\
\hline EPS & $-.242^{*}$ & .041 & .060 & -.069 & $.445^{* *}$ & -.167 & -.030 & 1 & & \\
\hline DOL & $.339^{* *}$ & $.475^{* *}$ & $.449^{* *}$ & $.466^{* *}$ & -.079 & $.439^{* *}$ & $-.224^{*}$ & -.052 & 1 & \\
\hline INDFIN & .169 & $.405^{* *}$ & $.372^{* *}$ & $.620^{* *}$ & .032 & $.204^{*}$ & -.128 & -.145 & $.289^{* *}$ & 1 \\
\hline
\end{tabular}

Asterisk * denotes significance at the 5\% level (2-tailed). Asterisk ** denotes significance at the 1 level (2-tailed). BETA is stock's market risk, CGDI_U is un-weighted corporate governance disclosure index, CGDI_W is weighted corporate governance disclosure index; DFL is degree of financial leverage measured by the debt to equity ratio; DIV is the dividend payout per share, Size is the log of average market size of sample firms; MVBV is the average market-to-book ratio of the sample firms; EPS is earning per share; DOL is the degree of operating leverage measure as $\log (\mathrm{EBIT}) / \log$ (Sales); INDFIN is the dichotomous variable, INDFIN $=1$, if the sample firm belongs to Bank and Financial Service sector, otherwise INDFIN $=0$.

While the above evidence provides an initial support to our hypothesis, it is observed (in column 3) that CGDI_W also has a significant positive correlation with DFL, SIZE, DOL, and INDFIN variables. The relationship between the CGDI_W and DFL may imply that companies with more external debt finance require compliance with the governance codes. The relationship between the CGDI_W and SIZE may imply that larger firms are usually better governed than smaller ones. The relationship between CGDI_W and DOL may imply that well managed and better governed firms can afford to use more fixed costs. The relationship between CGDI_W and INDFIN implies that firms in the financial sector usually need to comply with the codes of corporate governance, due to regulatory supervision by the central bank. In summary, the stocks of well-governed firms are likely to be less risky for the investors, but it is depicted that corporate governance itself to a large extent is related to other factors. Therefore, the paper proceeds to apply multivariate regressions in order to reveal whether corporate governance per se has any significant effect on the level of market risk. 
The full sample regression results for Model 1 presented in Table 4 reveal that CGDI_W, DFL, MVBV, and DOL have a significant effect on the level of market beta. As expected, the coefficient of CGDI_W is found to be negative, meaning that the market risk declines when a firm improves the level of corporate governance by following particularly the international codes of corporate governance. It should be noted that the coefficient of CGDI_W is significant at the $10 \%$ level. This may suggest that that effect of improvement in the corporate governance on the level of market risk may be weaker and not uniform across the sample firms, which needs to be checked. As the first step, we applied step-wise regression method to estimate a parsimonious model by eliminating the insignificant variables. The results of Model 2 presented in Table 4 show that the CGDI_W remains significant explanatory variable along with the MVBV, EPS, and DOL variables, though the level of significance did not change. As a whole, the four variables CGDI_W, MVBV, EPS, and DOL explain about 28.8\% of the market risk as it is depicted from the level of adjusted $\mathrm{R}^{2}$ value of Model 2.

Table 4. Full sample and marketwise regression results

\begin{tabular}{|c|c|c|c|c|}
\hline & \multicolumn{2}{|c|}{ UAE Markets (Two markets combined) $\mathrm{N}=95$} & \multirow{2}{*}{$\begin{array}{l}\text { Dubai Market } \\
\mathrm{N}=44\end{array}$} & \multirow{2}{*}{$\begin{array}{l}\text { Abu Dhabi Market } \\
\mathrm{N}=51 \\
\text { Model } 4\end{array}$} \\
\hline & Model 1 & Model 2 & & \\
\hline Constant & $\begin{array}{l}-0.774 \\
(-1.329)\end{array}$ & $\begin{array}{l}-0.256 \\
(-0.527)\end{array}$ & $\begin{array}{l}-1.993 \\
(-2.691)^{* * *}\end{array}$ & $\begin{array}{l}0.901 \\
(8.368)^{* * *}\end{array}$ \\
\hline CGDI_U & $\begin{array}{l}-0.079 \\
(1.093)\end{array}$ & & & \\
\hline CGDI_W & $\begin{array}{l}-0.031 \\
(-1.912)^{*}\end{array}$ & $\begin{array}{l}-0.005 \\
(-1.890)^{*}\end{array}$ & $\begin{array}{l}-0.008 \\
(-2.931)^{* * *}\end{array}$ & $\begin{array}{l}-0.003 \\
(1.691)^{*}\end{array}$ \\
\hline DFL & $\begin{array}{l}-0.049 \\
(-1.855)^{*}\end{array}$ & & $\begin{array}{l}-0.070 \\
(-2.743)^{* * *}\end{array}$ & \\
\hline DIV & $\begin{array}{l}-0.008 \\
(-1.009)\end{array}$ & & & \\
\hline SIZE & $\begin{array}{l}0.108 \\
(1.586)\end{array}$ & & $\begin{array}{l}0.539 \\
(4.412)^{* * *}\end{array}$ & \\
\hline MVBV & $\begin{array}{l}-0.272 \\
(-4.386)^{* * *}\end{array}$ & $\begin{array}{l}-0.254 \\
(-4.372)^{* * *}\end{array}$ & $\begin{array}{l}-0.292 \\
(-3.534)^{* * *}\end{array}$ & $\begin{array}{l}-0.233 \\
(-3.472)^{* * *}\end{array}$ \\
\hline EPS & $\begin{array}{l}-0.005 \\
(-1.606)\end{array}$ & $\begin{array}{l}-0.008 \\
(-2.762)^{* * *}\end{array}$ & $\begin{array}{l}-0.006 \\
(-2.031)^{* *}\end{array}$ & \\
\hline DOL & $\begin{array}{l}0.063 \\
(1.700)^{*}\end{array}$ & $\begin{array}{l}0.077 \\
(2.676)^{* * *}\end{array}$ & & $\begin{array}{l}0.116 \\
(2.982)^{* * *}\end{array}$ \\
\hline INDFIN & $\begin{array}{l}0.151 \\
(0.958)\end{array}$ & & & \\
\hline Adjusted $\mathrm{R}^{2}$ & 0.296 & 0.288 & 0.487 & 0.324 \\
\hline F Value & $5.393^{* * *}$ & $13.622^{* * *}$ & $11.204^{* * *}$ & $12.973^{* * *}$ \\
\hline
\end{tabular}

Asterisk * denotes significance at the $10 \%$ level. Asterisk ** denotes significance at the $5 \%$ level. Asterisk *** denotes significance at the $1 \%$ level. BETA is stock's market risk, CGDI_U is unweighted corporate governance disclosure index, CGDI_W is weighted corporate governance disclosure index; DFL is degree of financial leverage measured by the debt to equity ratio; DIV is the dividend payout per share, Size is the log of average market size of sample firms; MVBV is the average market-to-book ratio of the sample firms; EPS is earning per share; DOL is the degree of operating leverage measure as $\log (\mathrm{EBIT}) / \log (\mathrm{Sales})$; INDFIN is the dichotomous variable, INDFIN $=1$, if the sample firm belongs to Bank and Financial Service sector, otherwise INDFIN $=0$. It is noted that, in the Models 2,3 , and 4 , we have applied the step-wise regression method to remove the variables having insignificant effect on the dependent variable: beta coefficient. Thereby, we report the parsimonious models which include only the relevant variables that significantly affect the beta coefficient. If the less important variables are excluded from the models, the multicolinearity problem (when the excluded variables are endogenously related to the included variables) may be reduced and the coefficient of the included variables will be more consistent and reliable.

In the next step, we examine the effect of corporate governance on the security's market risk at Dubai and Abu Dhabi stock markets separately in Model 3 and Model 4. It is found that the effect of corporate governance disclosure on the market risk of security in the Dubai market is much stronger than that in the Abu Dhabi market, as depicted by the CGDI_W coefficients of Models 3 and 4. The CGDI_W coefficient of Model 3 that is applied on the Dubai market is significant at the $1 \%$ level, while that of the Model 4, which is applied on the Abu Dhabi market, is significant at only the $10 \%$ level. We cannot provide a clear explanation of why the two markets within same country behave in this somewhat different manner, but it is likely that Dubai investors are more conscious of the governance issues as Dubai becomes a major financial hub in the Middle East region with the establishment of Dubai International Financial Exchange (DIFX) in 2005. 
Although the negative effect of corporate governance disclosure on the level of security's market risk is found in both markets of the UAE, additional efforts are made to examine whether such effects are uniform across the different groups of sub-samples. Based on the significant correlation between the CGDI_W and other explanatory variables, we have classified samples into different sub-groups: high vs. low financial leverage firms; high vs. low operating leverage firms; small vs. large firms; and finance vs. non-finance firms. The detailed results of regression analyses that are available in Table 5 below indicate that the effect of corporate governance disclosure on the level of security's market risk is not uniform across the sub-samples.

Table 5. Sub-sample regression results

\begin{tabular}{|c|c|c|c|c|c|c|c|c|}
\hline & 1 & 2 & 3 & 4 & 5 & 6 & 7 & 8 \\
\hline & High & Low & High & Low & & & & \\
\hline Explanatory & Financial & Financial & Operating & Operating & Large & Small & Finance & Non-Finance \\
\hline \multirow[t]{2}{*}{ Variables } & $\begin{array}{l}\text { Leverage } \\
\text { Firms }\end{array}$ & $\begin{array}{l}\text { leverage } \\
\text { Firms }\end{array}$ & $\begin{array}{l}\text { Leverage } \\
\text { Firms }\end{array}$ & $\begin{array}{l}\text { Leverage } \\
\text { Firms }\end{array}$ & Firms & Firms & Firms & Firms \\
\hline & $\mathrm{N}=47$ & $\mathrm{~N}=48$ & $\mathrm{~N}=47$ & $\mathrm{~N}=48$ & $\mathrm{~N}=50$ & $\mathrm{~N}=45$ & $\mathrm{~N}=27$ & $\mathrm{~N}=68$ \\
\hline Constant & $\begin{array}{c}1.015 \\
(8.396)^{* * *}\end{array}$ & $\begin{array}{c}-0.93 \\
(-1.316)\end{array}$ & $\begin{array}{c}-4.117 \\
(-2.866)^{* * *}\end{array}$ & $\begin{array}{c}0.739 \\
(6.311)^{* * *}\end{array}$ & $\begin{array}{c}-3.68 \\
(-3.099)\end{array}$ & $\begin{array}{c}0.83 \\
(6.491)^{* * *}\end{array}$ & $\begin{array}{c}-0.477 \\
(-0.593)\end{array}$ & $\begin{array}{c}-1.412 \\
(-1.975)^{*}\end{array}$ \\
\hline CGDI U & & & & & & & & \\
\hline CGDI_W & $\begin{array}{c}-0.003 \\
(-1.78)^{*}\end{array}$ & ${ }^{-0.004}$ & $\begin{array}{c}-0.01 \\
(-2.855)^{* * *}\end{array}$ & & $\begin{array}{c}-0.004 \\
(-1.941)^{*}\end{array}$ & $\begin{array}{c}0.011 \\
(-3.011)^{* * *}\end{array}$ & & $\begin{array}{c}-0.009 \\
(-2.356)^{* *}\end{array}$ \\
\hline DFL & & & $\begin{array}{c}-0.056 \\
(-2.491)^{* *}\end{array}$ & & $\begin{array}{c}-0.045 \\
(-2.231)^{* *}\end{array}$ & & $\begin{array}{c}-0.065 \\
(-2.153)^{* *}\end{array}$ & \\
\hline DIV & & & & & & & & $\begin{array}{c}-0.022 \\
(-2.603)^{* * *}\end{array}$ \\
\hline SIZE & & $\begin{array}{c}0.299 \\
(2.601)^{* * *}\end{array}$ & & & $\begin{array}{c}0.5 \\
(3.013)^{* * *}\end{array}$ & & & $\begin{array}{c}0.232 \\
(2.069)^{* *}\end{array}$ \\
\hline MVBV & $\begin{array}{c}-0.26 \\
(-3.531)^{* * *}\end{array}$ & $\begin{array}{c}-0.218 \\
(-2.452)^{* *}\end{array}$ & $\begin{array}{c}-0.211 \\
(-2.104)^{* *}\end{array}$ & $\begin{array}{c}-0.23 \\
(-3.357)^{* *}\end{array}$ & $\begin{array}{c}-0.279 \\
(-4.031)^{* * *}\end{array}$ & $\begin{array}{c}-0.27 \\
(-3.002)^{* * *}\end{array}$ & $\begin{array}{c}-0.222 \\
(-2.134)^{* *}\end{array}$ & $\begin{array}{c}-0.286 \\
(-4.166)^{* * *}\end{array}$ \\
\hline EPS & $\begin{array}{c}-0.101 \\
(-1.681)^{*}\end{array}$ & & & $\begin{array}{c}-0.005 \\
(-1.898)^{*}\end{array}$ & $\begin{array}{c}-0.116 \\
(-2.632)^{* * *}\end{array}$ & $\begin{array}{c}-0.006 \\
(-2.149)^{* *}\end{array}$ & & \\
\hline DOL & $\begin{array}{c}0.086 \\
(1.950)^{*}\end{array}$ & & $\begin{array}{c}0.308 \\
(3.728)^{* * *}\end{array}$ & & $\begin{array}{c}0.11 \\
(2.545)^{* *}\end{array}$ & & $\begin{array}{c}0.112 \\
(2.201)^{* *}\end{array}$ & $\begin{array}{c}0.069 \\
(1.768)^{*}\end{array}$ \\
\hline INDFIN & & $\begin{array}{c}0.577 \\
(2.281)^{* *}\end{array}$ & & & & & & \\
\hline $\begin{array}{l}\text { Adjusted } \mathrm{R}^{2} \\
\text { F Value }\end{array}$ & $\begin{array}{c}0.329 \\
8.508^{* * *}\end{array}$ & $\begin{array}{c}0.352 \\
7.382^{* * *}\end{array}$ & $\begin{array}{c}0.347 \\
7.123^{* * *}\end{array}$ & $\begin{array}{c}0.201 \\
6.921^{* * *}\end{array}$ & $\begin{array}{c}0.451 \\
7.699^{* * *}\end{array}$ & $\begin{array}{c}0.22 \\
7.193^{* * *}\end{array}$ & $\begin{array}{c}0.276 \\
3.473^{* *}\end{array}$ & $\begin{array}{c}0.37 \\
10.819^{* * *}\end{array}$ \\
\hline
\end{tabular}

Asterisk * denotes significance at the $10 \%$ level. Asterisk ** denotes significance at the $5 \%$ level. Asterisk *** denotes significance at the $1 \%$ level. BETA is stock's market risk, CGDI_U is unweighted corporate governance disclosure index, CGDI_W is weighted corporate governance disclosure index; DFL is degree of financial leverage measured by the debt to equity ratio; DIV is the dividend payout per share, Size is the log of average market size of sample firms; MVBV is the average market-to-book ratio of the sample firms; EPS is earning per share; DOL is the degree of operating leverage measure as $\log (\mathrm{EBIT}) / \log (\mathrm{Sales})$; INDFIN is the dichotomous variable, INDFIN $=1$, if the sample firm belongs to Bank and Financial Service sector, otherwise INDFIN $=0$. The High Financial Leverage Firms are those with debt-equity (DE) ratio greater than the median DE ratio (1.09). The Low Financial Leverage firms are those with debt-equity (DE) ratio smaller than the median DE ratio. High Operating Leverage firms are those with DOL ratio greater than median value (16.08) and the Low Operating Leverage firms are those with the ratio smaller than the median. The large firms are those belonging to the group above the median firm size while the small firms are those belonging to the group below the median. Finance firms are those belonging to banking and financial services sectors. It is noted that we have applied the step-wise regression method to remove the variables having insignificant effect on the dependent variable: beta coefficient. Thereby, we report the parsimonious models, which include only the relevant variables that significantly affect the beta coefficient. If the less important variables are excluded from the models, the multicolinearity problem (when the excluded variables are endogenously related to the included variables) may be reduced and the coefficient of the included variables will be more consistent and reliable.

It is found that the regression coefficient of CGDI_W for the high financial leverage firms is less significant than that of the low financial leverage firms. This may suggest that companies with more external debt finance usually maintain a higher level of governance standards by compliance of mandatory governance codes as well as voluntary adoption of different good governance measures due to the monitoring of lending agencies. Therefore, disclosure of corporate governance information may not provide additional useful information to the general investors. If a firm does not borrow a significant amount of money from the external sources then the firm is less likely to be monitored by the lending agencies and any disclosure of corporate governance information may carry greater importance for the investors. Reviewing the results in columns 3 and 4, it is found that the coefficient of CGDI_W is highly significant for the high operating leverage firms, but the coefficient is 
not significant for the low operating leverage firms. This may suggest that firms with higher business risk must show good governance practices, and disclosure of corporate governance information is highly important to the general investors. If a firm has low business risks then investors perhaps pay less attention to the level of corporate governance as their cash flow may be less affected due to lower business risks.

It is also found (in columns 5 and 6) that disclosure of corporate governance information has a stronger effect on the security's market risk of the smaller firms relative to that of larger firms. This may be the case because larger firms are usually considered less risky. If this is so, then disclosure of corporate governance information may carry relatively less importance to the investors. On the other hand, smaller firms are usually considered more risky, and any disclosure of corporate governance information is very useful for the investors. It is also found (in columns 7 and 8) that disclosure of corporate governance information has no effect on the security's market risk of the finance firms, but has a stronger effect on that of the non-finance firms. This could be the case because finance firms are closely controlled and monitored by the central bank and the other government agencies. Therefore, the disclosure of corporate governance information by the finance firms may be less important to the investors, whereas the non-finance manufacturing, trade and service providing firms are usually not monitored by any statutory agency, expect perhaps by the security market authority. Therefore, disclosure of corporate governance information by these firms becomes important to the general investors.

In summary, the study has found that well-governed UAE corporate firms have significantly lower market risk after controlling for the other effects. Therefore, we can accept the hypothesis that the better the level of corporate governance the lower will be security's market risk. However, the effect of corporate governance disclosure is not uniform across the samples. Particularly, corporate governance disclosure does not display any significant effect on the low operating leverage firms or finance firms.

\section{Conclusions}

Corporate governance has drawn significant attention across the globe. The UAE is one such country in the Arabian Gulf area that has recently introduced its own code of corporate governance, and made it mandatory for the firms listed on the Dubai and Abu Dhabi stock markets. The prior international evidence generally revealed that companies that are able to improve their governance standards have received favorable market acceptance, resulting in higher market valuation of firms. In this paper, we made efforts to examine from the perspective of asset pricing theory why the well-governed firms should receive higher market valuation. The capital asset pricing theory suggests that the valuation of low-risk securities is higher because of the lower required return. Among the factors that affect the investors' required return, the security's market risk (beta) is still considered as an important risk factor. Therefore, we hypothesized that disclosure of the information related to corporate governance may help reduce the security's market risk because such information will be useful for the market to forecast cash flow more accurately.

We test several multivariate regression models using the weighted and un-weighted corporate governance disclosure indices developed by Hassan (2012). In these models, the market risk factor (beta coefficient) is used as the dependent variable while corporate governance disclosure indices are used as explanatory variables. The models are tested using a sample of 95 firms listed on the Dubai and Abu Dhabi stock markets. The results show that weighted corporate governance disclosure index has a significant negative effect on the security's market risk, yet the effect of un-weighted index is not significant. As a whole, results indicate that improvements in governance standards may lead to a reduction of a security's market risk, although some exceptions are found. For example, the disclosure of corporate governance information by the low operating leverage firms and finance firms does not affect their market risk. In addition, the effect of corporate governance information disclosure is found to be stronger in the low financial leverage firms, high operating leverage firms, and small sized firms compare to that of the other groups.

Therefore, it can be concluded that the securities of well-governed firms may be valued higher because the investors require a lower return due to lower market risk. Until evidence is obtained from different international markets, we attribute this conclusion only to the UAE capital markets. Policy makers can benefit from the finding that only weighted corporate governance index, which emphasizes on the international governance codes affects the market risk. This will help them to review local UAE codes for further improvement. Finally, the findings of this study leave open the question for future research as to why the impact of disclosure of corporate governance information differs across operating and financial leverages, firm sizes, and financial sectors.

\section{Acknowledgements}

We acknowledge the anonymous discussants on this paper presented at $I^{\text {st }}$ International Conference on Excellence in Business, May 9-10, 2012, Sharjah, United Arab Emirates. 


\section{References}

Acharya, V. V., \& Pedersen, L. H. (2005). Asset pricing with liquidity risk. Journal of Financial Economics, 77, 375-410. http://dx.doi.org/10.1016/j.jfineco.2004.06.007

Aljiifri, K., \& Moustafa, M. (2007). The impact of corporate governance mechanisms on the performance of UAE firms: An empirical analysis. Journal of Economic and Administrative Sciences, 23(2), 71-93. http://dx.doi.org/10.1108/10264116200700008

Aljiifri, K., \& Moustafa, M. (2012). Corporate governance mechanisms and capital structure in UAE. Journal of Accounting Research, 13(2), 145-160. http://dx.doi.org/10.1108/09675421211254849

Al-Tamimi, H. A. H. (2012). The effects of corporate governance on performance and financial distress: The experience of UAE national banks. Journal of Financial Regulation and Compliance, 20(2), 169-181. http://dx.doi.org/10.1108/13581981211218315

Ammann, M., Oesch, D., \& Schmid, M. M. (2011). Corporate governance and firm value: international evidence. Journal of Empirical Finance, 18(1), 36-55. http://dx.doi.org/10.1016/j.jempfin.2010.10.003

Anderson, C. A., \& Anthony, R. N. (1986). The new corporate directors: Insights for board members and executives. New York: John Wiley \& Sons.

Andres, P. D., Azrofra, V., \& Lopez, F. (2005). Corporate boards in OECD countries: Size, composition, functioning and effectiveness. Corporate Governance: An International Review, 13(2), 197-210. http://dx.doi.org/10.1111/j.1467-8683.2005.00418.x

Balasubramanian, N., Black, B. S., \& Khanna, V. (2010). The relation between firm-level corporate governance and market value: A case study of India. Emerging Markets Review, 11(4), 319-340. http://dx.doi.org/10.1016/j.ememar.2010.05.001

Black, B. (2001). Does corporate governance matter? A crude test using Russian data. University of Pennsylvania Law Review, 149, 2131-2150. http://dx.doi.org/10.2307/3312907

Black, B., \& Kim, W. (2012). The effect of board structure on firm value: A multiple identification strategies approach using Korean data. Journal of Financial Economics, 104(1), 203-226. http://dx.doi.org/10.1016/j.jineco.2011.08.001

Black, B., Jang, H., \& Kim, W. (2006). Does corporate governance predict firms' market value? Evidence from Korea. The Journal of Law, Economics, \& Organization, 22, 366-413. http://dx.doi.org/10.1093/jleo/ewj018

Cheung, Y., Connelly, J. T., Limpaphayom, P., \& Zhou, L. (2007). Do investors really value corporate governance? Evidence from the Hong Kong market. Journal of International Financial Management and Accounting, 18(2), 86-122. http://dx.doi.org/10.1111/j.1467-646X.2007.01009.x

Chong, A., \& Silanes, F. L. D. (2007). Overview: Corporate governance in Latin America. Investor protection and corporate governance: Firm level evidence across Latin America. The World Bank, and The Inter-American Development Bank: Stanford University Press.

Cotter, J., \& Silvester, M. (2003). Board and monitoring committee independence. Abacus, 39(2), 211-232. http://dx.doi.org/10.1111/1467-6281.00127

Dey, A. (2008). Corporate governance and agency conflict. Journal of Accounting Research, 46(5), 1143-1181. http://dx.doi.org/10.1111/j.1475-679X.2008.00301.x

Dimson, E. (1979). Risk measurement when shares are subject to infrequent trading. Journal of Financial Economics, 7(2), 197-226. http://dx.doi.org/10.1016/0304-405X(79)90013-8

Fama, E. F., \& French, K. R. (1993). Common risk factors in returns on stocks and bonds. Journal of Financial Economics, 33, 3-56. http://dx.doi.org/10.1016/0304-405X(93)90023-5

Fama, E. F., \& Jensen, M. (1983). Separation of ownership and control. Journal of Law and Economics, 26, 301-325. http://dx.doi.org/10.1086/467037

Farooque, O., Zijl, V. T., Dunstan, K., \& Karim, A. K. M. W. (2007). Corporate governance in Bangladesh: Link between ownership and financial performance. Corporate Governance: An International Review, 15(6), 1453-1468. http://dx.doi.org/10.1111/j.1467-8683.2007.00657.x

Fernandes, N. (2008). EC: Board compensation and firm performance: the role of independent board members. $\begin{array}{llll}\text { Journal of Multinational } & \text { Financial } & \text { 30-40. }\end{array}$ 
http://dx.doi.org/10.1016/j.mulfin.2007.02.003

Florackis, C., \& Ozkan, A. (2009). The impact of managerial entrenchment on agency costs: An empirical investigation using UK panel data. European Financial Management, 15(3), 497-528. http://dx.doi.org/10.1111/j.1468-036X.2007.00418.x

Gandia, J. (2008). Determinates of internet-based corporate governance disclosure by Spanish listed companies. Online Information Review Journal, 32(6), 791-817. http://dx.doi.org/10.1108/14684520810923944

Garay, U., \& Gonzalez, M. (2008). Corporate governance and firm value: The case of Venezuela. Corporate Governance: An International Review, 16(3), 194-209. http://dx.doi.org/10.1111/j.1467-8683.2008.00680.x

Gompers, P., Ishii, J., \& Metrick, A. (2003). Corporate governance and equity prices. Quarterly Journal of Economics, 118, 107-155. http://dx.doi.org/10.1162/00335530360535162

Gorton, G., \& Kahl, M. (2008). Blockholder scarcity, takeovers, and ownership structures. Journal of Financial \& Quantitative Analysis, 43(4), 937-974. http://dx.doi.org/10.1017/S002210900001440X

Haat, M. H., Abdul Rahman, R., \& Mahenthiran, S. (2008). Corporate governance, transparency and performance of Malaysian companies. Managerial Auditing Journal, 23(8), 744-778. http://dx.doi.org/10.1108/02686900810899518

Hamada, R. S. (1972). The effect of the firm's capital structure on the systematic risk of common stock. Journal of Finance, 27(2), 435-452. http://dx.doi.org/10.2307/2978486

Haniffa, R. M., \& Cooke, T. E. (2002). Culture, corporate governance and disclosure in Malaysian corporations. ABACUS: Journal of Accounting, Finance and Business Studies, 38(3), 317-349. http://dx.doi.org/10.1111/1467-6281.00112

Hart, O. (1995). Corporate governance: Some theory and implication. The Economic Journal, 105, 678-689. http://dx.doi.org/10.2307/2235027

Hassan, M. K. (2012). A disclosure index to measure the extent of corporate governance reporting by UAE listed corporations. Journal of Financial Reporting and Accounting, 10(1), 4-33. http://dx.doi.org/10.1108/19852511211237426

Ho, Y. K., Xu, Z., \& Yap, C. M. (2004). R\&D investment and systematic risk. Accounting and Finance, 44, $393-$ 418. http://dx.doi.org/10.1111/j.1467-629x.2004.00116.x

Hu, H. W., Tam, O. K., \& Tan, M. G. S. (2010). Internal governance mechanisms and firm performance in China. Asia Pacific Journal of Management, 27(4), 727-749. http://dx.doi.org/10.1007/s10490-009-9135-6

Hussainey, K., \& Al-Nodel, A. (2008). Corporate governance online reporting by Saudi listed companies. $\begin{array}{lllll}\text { Research in Accounting in Emerging Economies, } & \text { 8, }\end{array}$ http://dx.doi.org/10.1016/S1479-3563(08)08002-X

Jensen, M. C. (1993). The modern industrial revolution, exit, and the failure of internal control system. Journal of Finance, 48, 831-880. http://dx.doi.org/10.1111/j.1540-6261.1993.tb04022.x

Joh, S. W. (2003). Corporate governance and firm profitability: Evidence from Korea before the economic crisis. Journal of Financial Economics, 68, 287-322. http://dx.doi.org/10.1016/S0304-405X(03)00068-0

Klapper, L. F., \& Love, I. (2004). Corporate governance, investor protection, and performance in emerging markets. Journal of Corporate Finance, 10, 703-728. http://dx.doi.org/10.1016/S0929-1199(03)00046-4

Lei, A. C. H., \& Song, F. M. (2012). Board structure, corporate governance and firm value: evidence from Hong Kong. Applied Financial Economics, 22(15), 1289-1303. http://dx.doi.org/10.1080/09603107.2011.650329

Lins, K. V. (2003). Equity ownership and firm value in emerging markets. Journal of Financial and Quantitative Analysis, 38(1), 159-184. http://dx.doi.org/10.2307/4126768

Love, I. (2011). Corporate governance and performance around the world: What we know and what we don't. The World Bank Research Observer, 26, 42-70. http://dx.doi.org/10.1093/wbro/lkp030

Mandelker, G. N., \& Rhee, S. G. (1984). The impact of the degree of operating and financial leverage on systematic risk of common stock. Journal of Financial \& Quantitative Analysis, 19(1), 45-57. http://dx.doi.org/10.2307/2331000

McKnight, P. J., \& Weir, C. (2009). Agency costs, corporate mechanisms and ownership structure in large UK publicly quoted companies: A panel data analysis. Quarterly Review of Economics \& Finance, 49(2), 139- 
158. http://dx.doi.org/10.1016/j.qref.2007.09.008

Newell, R., \& Wilson, G. (2002). A premium for good governance. McKinsey Quarterly.

Porta, R. L., Silanes, F. L. D., Shleifer, A., \& Vishney, R. (2000). Investor protection and corporate governance. Journal of Financial Economics, 58, 3-27. http://dx.doi.org/10.1016/S0304-405X(00)00065-9

Schmid, M. M., \& Zimmermann, H. (2008). Leadership structure and corporate governance in Switzerland. $\begin{array}{llll}\text { Journal of Applied } & \text { Corporate } & \text { Finance, }\end{array}$ http://dx.doi.org/10.1111/j.1745-6622.2008.00173.x

Shleifer, A., \& Vishney, R. W. (1997). A survey of corporate governance. Journal of Finance, 52, 737-83. http://dx.doi.org/10.2307/2329497

Skaife, H. A., Collins, D. W., \& LaFond, R. (2004). Corporate governance and the cost of equity capital. Retrieved from http://ssrn.com/abstract=639681. http://dx.doi.org/10.2139/ssrn.639681

Slovin, M., \& Sushka, M. (1993). Ownership concentration, corporate control activity, and firm value: Evidence from the death of inside blockholders. Journal of Finance, 48(2), 1293-1321. http://dx.doi.org/10.2307/2329039

Stoeberl, P. A., \& Sherony, B. C. (1985). Board efficiency and effectiveness. In E. Mattar \& M. Balls (Eds.), Handbook for corporate directors. New York: McGraw-Hill.

Stulz, R. (1988). Managerial control of voting rights: Financing policies and the market for corporate control. Journal of Financial Economics, 20, 25-54. http://dx.doi.org/10.1016/0304-405X(88)90039-6

Thompson II, D. J. (1976). Sources of systematic risk in common stocks. Journal of Business, 49(2), 173-188. http://dx.doi.org/10.1086/295829

\section{Notes}

Note 1. http://www.thefirstgroup.com/dubai-property-investment-news/article.php?id=800473760

Note 2. We have checked the 'beta co-efficient' estimates for the sample firms based on the daily stock prices and compare them with those calculated based on the weekly price data. The distribution of weekly beta is more symmetric than the distribution of the daily beta. Moreover, it was found that many UAE stocks are not traded frequently on the daily basis that may lead to the thin trading bias on the daily beta estimates. Also the standard deviation of daily returns is higher than that of weekly returns. Hence, we have relied on the weekly beta to avoid daily abnormal fluctuations and thin trading problems.

Note 3. The annual report is usually published within the first quarter following the financial year and it is the main document that contains important discourses on the corporate governance information.

Note 4. Haniffa and Cooke (2002); Dey (2008); Cheung et al. (2007); Klapper and Love (2004); Haat et al. (2008); Hussainey and Al-Nodel (2008); Gandia (2008).

\section{Appendix}

Appendix 1. Items in corporate governance disclosure index

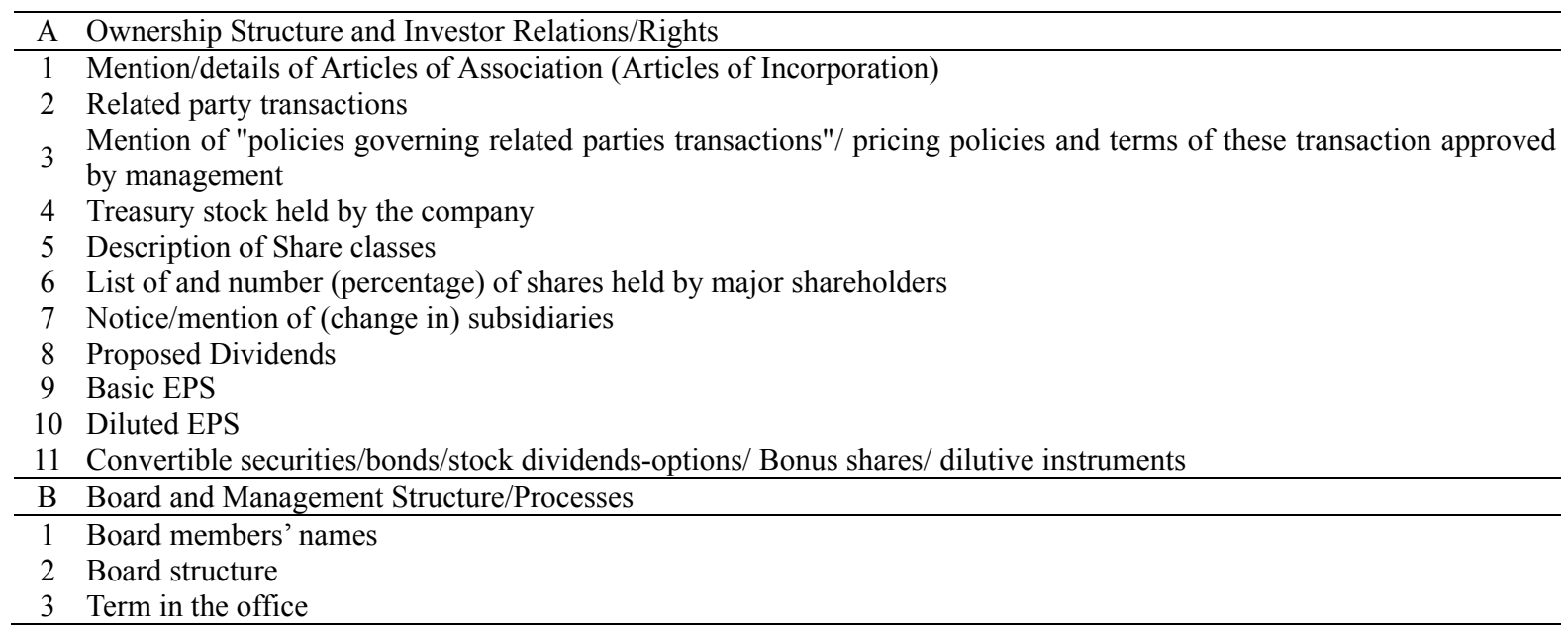




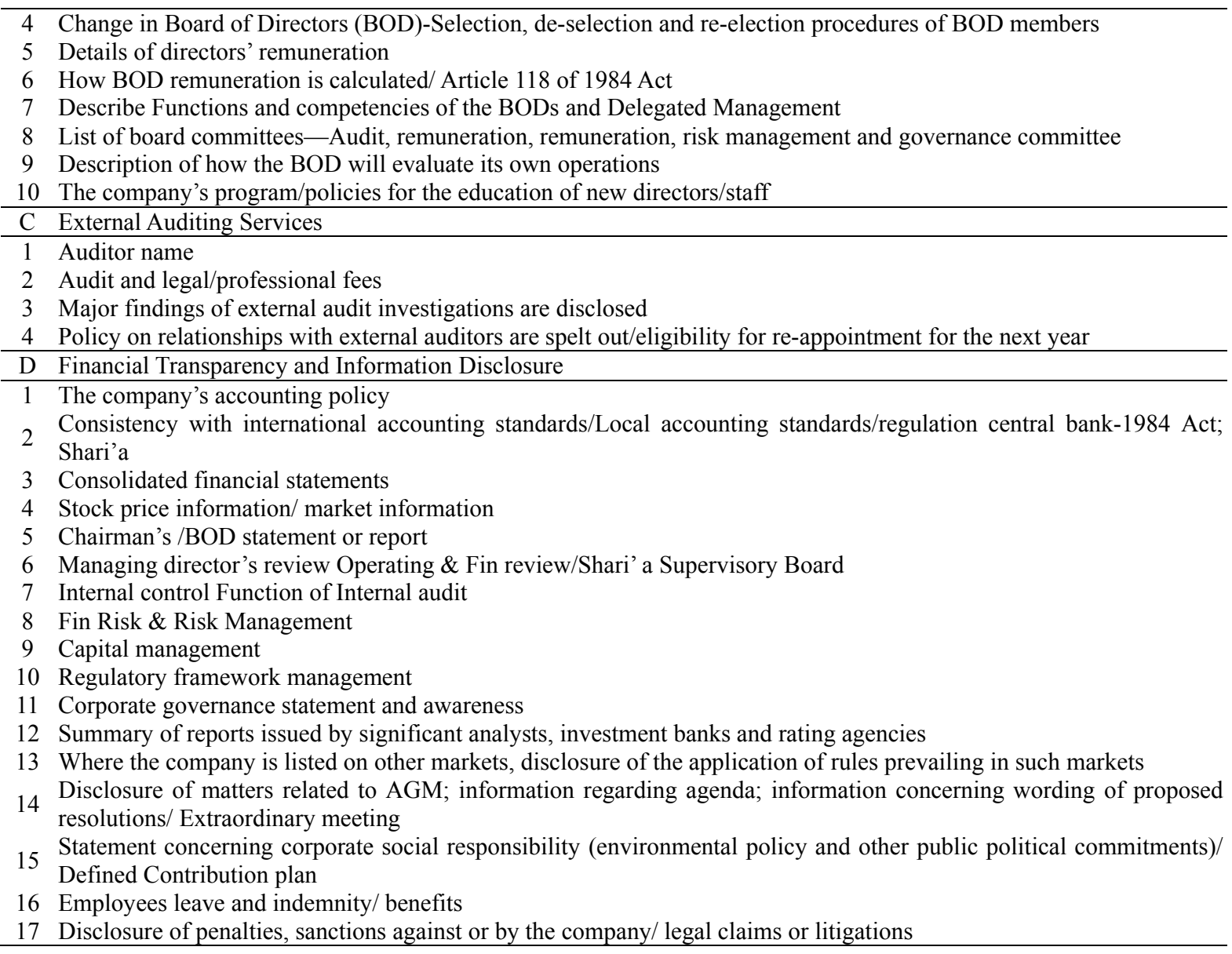

Source: Hassan (2012).

\section{Copyrights}

Copyright for this article is retained by the author(s), with first publication rights granted to the journal.

This is an open-access article distributed under the terms and conditions of the Creative Commons Attribution license (http://creativecommons.org/licenses/by/3.0/). 